NBER WORKING PAPER SERIES

A NOTE ON SUBSIDIZING GIFTS

Louis Kaplow

Working Paper No. 4868
NATIONAL BUREAU OF ECONOMIC RESEARCH
1050 Massachusetts Avenue
Cambridge, MA 02138
September 1994

Comments from Steven Shavell are greatly appreciated. This paper is part of NBER's research programs in Law and Economics, and Public Economics. Any opinions expressed are those of the author and not those of the National Bureau of Economic Research.

(C) 1994 by Louis Kaplow. All rights reserved. Short sections of text, not to exceed two paragraphs, may be quoted without explicit permission provided that full credit, including () notice, is given to the source. 


\title{
A NOTE ON SUBSIDIZING GIFTS
}

\begin{abstract}
Altruistically motivated gifts involve a species of consumption externality. Donors obtain an altruistic benefit from the effect of their gifts on donees' utility but do not take into account that the benefit to donees is itself relevant to social welfare. The level of gift-giving thus will be lower than is optimal. A subsidy can correct this problem, while compulsory transfers (assuming the state lacks information about who is altruistic) and bargaining between donors and donees cannot. The rationale for subsidizing gifts offered here does not depend on whether the donee's activity is a public good (as with gifts for medical research) or whether the transfer tends to equalize the wealth of donors and donees -- factors emphasized in the existing literature on the subject.
\end{abstract}

\author{
Louis Kaplow \\ Harvard Law School \\ HFB 322 \\ Harvard University \\ Cambridge, MA 02138 \\ and NBER
}


Gift-giving -- notably transfers within the family and philanthropy -- is a significant economic phenomenon. ${ }^{1}$ Presumably, altruism is an important motivation for many gifts.2 This note compares the private and social benefits of altruistically motivated gifts and shows that subsidizing such gifts would increase social welfare.

Altruistically motivated gifts involve a species of consumption externality. ${ }^{3}$ An individualistic social welfare function includes both the donor's utility -- which depends in this instance on the donee's utility -- and the donee's utility in its own right. Thus, a gift, by increasing the donee's utility, enhances social welfare both because of the indirect effect on the donor's utility and the direct effect on the donee's. The donor, however, takes into account only the indirect effect. As a result, even a donor who weighs the donee's utility equally with his own does not account for the full effect of his gift on social welfare.

In the model analyzed in section 1 , social welfare can be raised with a subsidy. As explained in section 2, the rationale for subsidizing gifts offered here does not depend on whether the

1 For example, charitable giving In the U.S. has typically amounted to between two and three percent of national income. Clotfelter (1985, table 1.2).

2 To be sure, altrulsn hardly notlvates all glving. See Andreonl (1988), section 1.3 , and note 13 .

3 This point appears In Frledman (1988), who does not examine subsidies. Becker's (1974) well-known analys 18 also differs from that here, as he considers privately optimal allocations and how they affect individuals' Incentives, but not what allocation would be soclally optimal or how that allocation night be Induced. The Idea that the presence of altrulsm does not solve all problems to which it is applicable has recelved Increasing attention. See, for example, Bernheim and Stark (1988). 
donee's activity is a public good (as with gifts for medical research) or whether the transfer tends to equalize the wealth of donors and donees -- factors emphasized in the existing 1iterature on the subject. Atkinson (1976) is closest to the present inquiry. Although he addresses what tax treatment of charitable contributions is optimal from the perspective of redistribution, his formulation employs an explicit social welfare function and considers donors' motivations for giving in a similar manner.

The welfare consequences of gifts are of particular importance in light of existing policies that subsidize some forms of giving, as through tax exemptions and deductions. For example, the revenue loss from the charitable contribution deduction under the U.S. Cederal income tax in fiscal year 1994 is expected to be about twenty billion dollars. The revenue loss from step-up basis of capital gains at death (bequests being an important component of transfers to individuals) will be approximately fifty billion dollars. Relatedly, federal taxes on estates and gifts are estimated to exceed twelve billion dollars. [Budget of the United States Government (1993).]

1. Analysis

1.1. G1ftg In the Absence of Subsidies

There are two types of individuals, donees -- each of whose utility is a concave function, $v$, of his own wealth -- and donors -- each of whose utility is the sum of a concave function, $U$, of his own wealth and $\lambda$ times a respective donee's utility. (Each donor is paired with a donee.) Donors' and donees' initial 
levels of wealth are $w$ and $y$ respectively. Each donor chooses a gift, $g \in[0, w]$, to transfer to a donee, to maximize

(1). $U(w-g)+\lambda V(y+g)$.

The first-order condition for an interior solution is

(2) $\quad U^{\prime}=\lambda V^{\prime}$.

There will be no gift if donors' level of altruism is sufficiently small. For example, if $U(\cdot)=v(\cdot)$ and $w=y, g>0$ if and only if $\lambda>1$.

Assuming for simplicity that social welfare is the sum of utilities, the socially optimal g maximizes

(3) $(U+\lambda V)+V=U(w-g)+(1+\lambda) V(y+g)$.

The first-order condition for an interior solution is

(4) $U^{\prime}=(1+\lambda) V^{\prime}$.

Using the previous example of equal initial wealth and identical functions for utility of wealth, a positive transfer is optimal when $\lambda>0$. Moreover, the optimal transfer exceeds that which maximizes (1). The private and social optima differ because each donor counts the respective donee's utility only for its effect on the donor's own utility (no matter how large is the $\lambda$ ), while social welfare also includes the effect on the donee's utility in its own right. This divergence is reflected in the difference between the weights $\lambda$ and $1+\lambda$ in (1) and (3) or (2) and (4). 


\subsection{Optinal Subsidy}

If the social authority knew which individuals were donors and donees, the level of altruism, the initial levels of wealth, and the functional form for utility of individuals' own wealth, it simply could order the appropriate transfers. More realistically, much of this information will be unobservable (or costly to observe).

Assume, for example, that the social authority does not know who prospective donors and donees are, but that it does know $\lambda$, ldentical for all donors. When individuals begin with equal wealth and have the same functions for utility of own wealth, prospective donors will not give any gift when $\lambda<1$; hence, observing private behavior would be insufficient to reveal who was altruistic. Thus, the optimal compulsory transfer scheme involves no transfers, as there is no basis for determining who should be ordered to transfer to whom.

with the same assumption about information, consider a subsidy. Let $\mathrm{s}$ be the rate at which donors are subsidized, so that a donor's private cost of giving a gift g becomes (1-s)g. This subsidy is financed by a pro rata lump-sum tax that individuals take as given." It can be demonstrateds that the optimal subsidy rate is

\footnotetext{
- The analysis to follow demonstrates Implicitly that the effect of this tax on donors and donees' wealth disappears in equllibrium; donors are Induced to distribute walth between themselvas and donees optimally, so that the Increase in donor: giving is oufficlent to offset the tax pald by donees. If the subsidy were financed by distortlonary taxation, the optimal subsidy would differ.
}

S When the subsidy is $1 /(1+\lambda)$, the gift costs a donor $\lambda /(1+\lambda)$. Then, the derlvative of the donor's utility with respect to $g$ is 


$$
s=\frac{1}{1+\lambda}=\frac{V^{\prime}}{U^{\prime}}
$$

When there is an interior solution -- that is, when there is any giving in the presence of this subsidy scheme -- the subsidy Induces the first-best allocation of wealth because it internalizes the externality, which is $\mathrm{V}^{\prime}$, measured in utility units to the donor, $\mathrm{U}^{\prime} .{ }^{\circ}$

Note that when $\lambda$ is very small the subsidy rate approaches 100 of the amount of the transfer, but when $\lambda$ is very large (much larger than 1) the subsidy is very small, approaching zero in the limit. The intuition is that, without the subsidy, a donor weights the donee's utility by only $\lambda$ rather than $1+\lambda$; when $\lambda$ is near zero, the relative gap between the private and social valuations of $\mathrm{V}$ is very large, but when $\lambda$ is large, the relative gap is small (even though the absolute gap is the same, equal to 1 in both instances).

The subsidy in this simple model requires knowledge of $\lambda$, but is independent of wealth levels $w$ and $y$ and of utility functions $\mathrm{U}(\cdot)$ and $\mathrm{V}(\cdot)$. Consider briefly the case in which the level of $\lambda$ varies among potential donors and is not directly observable. In this instance, the optimal mechanism may well involve a subsidy, with the rate a function of the amount of individuals' gifts.

$$
\frac{\lambda}{1+\lambda} v^{\prime}+\lambda V^{\prime}
$$

which ylelds (4) as the first-order condition for the donor.

- When the first-best allocation requlres donees to glve to donors -- as it would if donees vere sufficlently wealthier than donors .. a subsidy would fall, resulting in the corner solution in which there is no giving. Also, note that when $\lambda-0,-1$, 1mplying that donors are indlfferent about the size of their gift; implicitly, the assumption in this case is that donors give the soclally optimal gift. 
Higher transfers would signal higher $\lambda$ 's and thus call for lower subsidy rates. of course, prospective donors would take this into account and may be induced to transfer less than they would if the subsidy rate were fixed. This is an instance of the familiar revelation problem [see Myerson (1979)], and an incentive-compatible mechanisin would not allow implementation of the first-best. Also note that, when $\lambda$ is not observable, the optimal scheme would depend upon initial wealth levels and individuals' utility functions. For example, if a donor has higher initial wealth, a lower $\lambda$ is implied by any level of giving, ceteris paribus. As a result, individuals with similar giving patterns would receive larger subsidies the greater their observed wealth.

\subsection{A More General Foraulation with Wara-Glow Giving}

An altruistic donor's utility might depend on the donee's wealth or utility in more subtle ways. Moreover, gifts might also be motivated by the benefit to the donor from the act of giving itself (warm glow), rather than purely by concern for the well-being of the beneficiary (Andreoni (1990)]. Instead of (1), the donor would maximize $U(w-g, y+g, g)$. In place of (5), the condition for the optimal subsidy would be

$$
s=\frac{2 V^{\prime}}{U_{1}+U_{2}+V^{\prime}}
$$

where $U_{1}$ is the derivative of $U$ with respect to argument $i$. Although not immediately apparent, expression (6) is essentially the same as (5) for the simple case.' In particular, the optimal

7 Expression (5) could also have been written as 
subsidy is lower when altruism, here indicated by the magnitude of $\mathrm{U}_{2}$, is greater. (The existence of a warm-glow motive does not affect the formula for the optimal subsidy: the externality -that the donor does not count $v$ directly -- exists regardless of the motive for giving. ${ }^{\circ}$ )

\section{Remarks}

(a) Why private agreement cannot internalize the gift externality. Private agreement cannot produce a first-best outcome, as with typical externalities." The reason is that a transfer of wealth itself is the source of the effect on social welfare. If a prospective donee offered a side payment, $p$, to a prospective donor in an attempt to induce the socially optimal gift, that payment would itself constitute undoing of the gift. (A gift of $g$ induced by a payment of $p$ is identical in the model to a gift of $g-p$ and no side payment.)

The problem arises because achleving the social optimum involves a redistribution of wealth. Although there is an

$$
a=\frac{2 V^{\prime}}{\mathrm{U}^{\prime}+\lambda V^{\prime}+V^{\prime}} .
$$

The intultion for (6) ... and this variation of (5) .. Is that donors 1gnore both the Independent benefit of their gift to donees, $v$, and the cost of the subsidy (the lump-sun tax 1s taken 18 given), which at the margin equals $s / 2$ (each pays half the subaldy cost) times the direct marginal utility of the donor, $U_{1}$, the donee, $V \cdot$, plus of the Indirect effect of the donee on the donor, $U_{3}$. Then $a$ is given by (6), external costs equal external benefits, so donors' declsions are optimal.

- The presence of a warm-glow motive will increase the level of giving for a given degree of altrulsm, which nay affect the optimal level of the subsidy because the relevant marginal utilities are affected. In the simple case in which al trulsa takes the form in the Initial model, the optimal subsidy equals $1 /(1+\lambda)$ regardless of any warm-glow notive. As a result, if evidence Indicates that a given level of observed giving is more explained by the warmglow effect than altrulsn, the optimal subsidy rate would be higher because $\lambda$ (reflected in (6) by $U_{2}$ ) would be lower.

- See Coase (1960). Frledman (1988) has Indicated that bargaining cannot eliminate this externality. 
externality in the sense that donors do not fully appropriate the benefit of their gifts, the private allocation (with no subsidy or compulsory transfer) is a pareto optimum -- one differing from that which maximizes the sum of utilities. It is familiar that individual decisionmaking will not maximize social welfare when matters of distribution are involved.

(b) Other rationales for subsidizing gifts. A frequently offered rationale for subsidy to charities also invokes the concept of externalities. It relies on the assumption that institutions receiving gifts use them in a way that creates positive externalities, as with medical research. ${ }^{10}$ It is not contemplated that, looking solely at the donor and donee (even if the donee is not a "charity"), there is an externality of sorts. ${ }^{11}$ Another common rationale for subsidy focuses on the redistributive dimension of giving -- i.e., the extent, if any, to which gifts involve transfers from rich to poor. In contrast, the discussion here emphasizes a rationale independent from both the nature of the recipient's activities and traditional redistribution, in that it holds even if the recipient spends the

10 It $1 \mathrm{~s}$ proposed that subsidies be used in an attempt to implement a Lindahl solution. See Hochman and Rogers (1977).

11 For example, Hochman and Rogers (1977, p. 3) state: "External beneflts must accrue in the demands for the specific services that charity finances. - to justify the public subsidization of charity. Otherwise, the benefits of giving are private, and no subsidy is warranted." This viewpoint perhaps explains why the literature focuses on gifts to pubilc charities, ignoring gifts to individuals. Of course, Income redistribution 1tself can be a public good, Justifying subsidy (or compulsory redistribution) on conventional externality grounds. Hochman and Rogers (1969) explain that such redistribution may be warranted because of the effect a wealthy donor's gift to a poor donee has on the utility of third parties (others whose utility depends on the welfare of the poor). Their focus, as the title to their we11known article suggests, is on the rediatribution necessary to reach a pareto optimu, not, as here, on inducing transfers that result in a social welfare maxinizing pareto optimus that differs from the private allocation, which is itself pareto optinal. 
gift on ordinary consumption and initial wealth is equal (or the donee is richer than the donor).

(c) Policy implications. The central conclusion derived here is that the optimal subsidy rate for gifts is positive. ${ }^{12}$ of course, any rationale for subsidizing gifts assumes that, as a practical matter, they can be distinguished from payments for goods or services. ${ }^{13}$ But the presence of return flows from beneficiaries to donors (which could even include returning the gift itself) would often be difficult to detect, particularly for gifts within the family.

This administrative constraint may be more of a problem with respect to private giving than contributions to public charities. Indeed, gifts to charities are subsidized, by the income tax deduction for charitable contributions and the exemption from many forms of taxation for charitable activity. ${ }^{4}$

Treatment of gifts to individuals is quite different. Although the income tax excludes gifts from donees' income (which some view as an implicit subsidy), donors get no deduction. Whatever its merits, this approach is surely more adininistrable

\footnotetext{
12 Although the conclusion does not depend on the additive (utllitarian) speciflcation of the soclal velfare function, it does depend upon a welfarist approach. The Inclusion of the donor's altrulstically derived utility may be controversial. But atisfaction from altrulsm, even if deemed selfish altrulsin, is arguably at least as virtuous as ordinary selfish pleasure. Moreover, If this source of utllity $1 \mathrm{~s}$ excluded from soclal welfare, the optlmal subsidy would equal $1-\lambda$, and thus would be negative - a tax - when $\lambda>1$.

13 For evidence that much giving is motivated by exchange rather than altrulsw, see Bernhelm, Shlelfer, and Sumers (1985) and Cox (1987).

14 Much of the 11terature on tax pollcy addresses the extent to whlch varlous tax policles encourage charitable giving. devoting ilttle attention to how much giving (and by whon) is soclally optlmal. For a discussion of emplrical work on charitable giving, see clotfelter (1985).
} 
than alternatives, particularly in light of the difficulty of the government in assessing whether private transfers are gifts or expenditures for goods and services. Nonetheless, large gifts and bequests are separately taxed, which is not consistent with the efficiency argument developed here.

The efficiency rationale also has implications for the form of an optimal subsidy; recall that the optimal subsidy rate is higher for less altruistic donors because the weight they give to donees is a relatively lower fraction of the socially appropriate weight. This implies, first, that the optimal subsidy rate is lower for larger gifts, to the extent they reflect greater altruism rather than higher income of the donor. Yet reformers often advocate that a floor be placed on the charitable contribution deduction, limiting the subsidy to large gifts. Second, the optimal subsidy is higher for gifts of a given size made by high-income donors, because their higher income implies a lower degree of altruism, ceteris paribus. As a result, a tax deduction -- worth more to those in higher tax brackets -- is not obviously inferior to a credit, which is often proposed as a replacement for the current deduction. ${ }^{15}$ It should be emphasized, however, that the efficiency property of a subsidy for giving is only one factor relevant to how a subsidy scheme or a tax system should treat gifts.

15 The present analyais, like that in Atkinson (1976), differs from that of many reformers, buch as vickrey (1947, 1975), because results are derived from an explicit weifare function, as urged by Stiglitz and Boskin (1977), rather than fron a atipulated reference polnt, such as a comprehensive definition of income. 


\section{References}

Andreoni, James, 1988, Privately Provided Public Goods in a Large Economy: The Limits of Altruism, Journal of Public Economics $35,57-73$.

- 1990, Impure Altruism and Donations to Public Goods: A Theory of Warm-Glow Giving, Economic Journal 100, 464-477.

Atkinson, A.B., 1976, The Income Tax Treatment of Charitable Contributions, in Ronald E. Grieson, ed. , Public and Urban Economics: Essays in Honor of William S. vickrey (New York: D.C. Heath), 13-29.

Becker, Gary S., 1974, A Theory of Social Interactions, Journal of Political Economy 82, 1063-1091.

Bernheim, B. Douglas, Andrei Shleifer, and Lawrence H. Summers, 1985, The Strategic Bequest Motive, Journal of Political Economy 93, 1045-1076.

and Oded Stark, 1988, Altruism within the Family Reconsidered: Do Nice Guys Finish Last?, American Economic Review 78, 1034-1045.

Budget of the United States Government: Fiscal Year 1991, 1990.

Clotfelter, Charles T., 1985, Federal Tax Policy and Charitable Giving (Chicago: University of Chicago Press).

Coase, Ronald H., 1960, The Problem of Social Cost, Journal of Law and Economics 3, 1-44.

Cox, Donald, 1987, Motives for Private Income Transfers, Journal of Political Economy 95, 508-546.

Friedman, David D., 1988, Does Altruism Produce Efficient Outcomes? Marshall versus Kaldor, Journal of Legal Studies 17, 1-13.

Hochman, harold M. and James D. Rogers, 1969, Pareto Optimal Redistribution, American Economic Review 59, 542-557.

and 1977 , The optimal Tax Treatment of Charitable Contributions, National Tax Journal 30, 1-18.

Myerson, Roger B., 1979, Incentive Compatibility and the Bargaining Problem, Econometrica 47, 61-73.

Stiglitz, Joseph E. and Kichael J. Boskin, 1977, Impact of Recent Developments in Public Finance Theory on Public Policy

Decisions, American Economic Review 67, 295-301.

Vickrey, william, 1947, Agenda for Progressive Taxation (New York: Ronald Press). - 1975, Private Philanthropy and Public Finance, in Edmund Phelps, ed., Altruism, Morality, and Economic Theory (New York: Russel Sage Foundation), 149-169. 